10 - ORIGINAL ARTICLE

EXPERIMENTAL SURGICAL INFECTIONS

\title{
Alcohol extract of Schinu sterebinthifolius raddi (anacardiaceae) as a local antimicrobial agent in severe autogenously fecal peritonitis in rats $^{1}$
}

\author{
Maria Cecília Santos Cavalcanti Melo ${ }^{\mathrm{I}}$, Diego Nery Benevides Gadelha" ${ }^{\mathrm{II}}$, Thárcia Kiara Beserra Oliveira ${ }^{\mathrm{III}}$, Carlos Teixeira Brandt ${ }^{\mathrm{IV}}$ \\ DOI: http://dx.doi.org/10.1590/S0102-86502014001300010 \\ IFellow PhD degree, Postgraduate Program in Surgery, Health Sciences Center, Federal University of Pernambuco (UFPE). Assistant Professor, \\ Department of Ophthalmology, Campina Grande Faculty of Medicine (FCM), Campina Grande-PB, Brazil. Acquisition and interpretation of data, \\ manuscript writing \\ ${ }^{\text {II }} \mathrm{MD}, \mathrm{PhD}$, Department of Ophthalmology, FCM, Campina Grande-PB, Brazil. Manuscript writing, critical revision

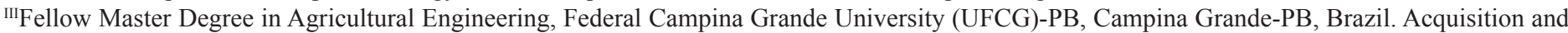 \\ interpretation of data \\ ${ }^{\mathrm{IV}} \mathrm{MD}, \mathrm{PhD}$, Head Professor, Scientific Methodology and Pediatric Surgery, UFPE, Recife-PE.Coordinator, FCM, Campina Grande-PB, Brazil. \\ Conception, design, intellectual and scientific content of the study, critical analysis, final approval of manuscript
}

\section{ABSTRACT}

PURPOSE: To develop an alcoholic extract of the inner bark of the Schinus terebinthifolius raddi and to test its impact on autogenously fecal peritonitis in Wistar rats.

METHODS: The inner bark of the Schinus terebinthifolius raddi was kept for seven days in $70 \%$ ethanol alcohol. The total elimination of the solvent was performed in a rotary evaporator under reduced pressure at $55-60^{\circ} \mathrm{C}$. Four milliliter of this extract was injected, after $24 \mathrm{~h}$, into the abdominal cavity of six out of eight survival rats that underwent autogenously fecal peritonitis with five milliliter of $10 \%$ filtered fecal suspension. They were clinically followed up for 45 days when they were euthanized. The necropsy findings (inventory) of the abdominal and thorax cavities were inspected and the main findings were recorded and photographed. The investigation was approved by the Ethics Committee.

RESULTS: Two out of six survival rats that were critically ill after $24 \mathrm{~h}$ died within the $12 \mathrm{~h}$ after the extract injection into the abdominal cavity. Four rats that were also critically ill recovered and gradually became healthy, eating well, regaining weight and moving normally in the cage. At 45 days post severe peritonitis the necropsy findings revealed few signs of residual infection on the abdominal and thorax cavities. There were no bowel adhesions.

CONCLUSION: The impact of alcoholic extract of the inner bark of the Schinus terebinthifolius raddi was considered very positive and promising as natural local antiseptic against very severe peritonitis in Wistar rats.

Key words: Peritonitis. Schinus terebinthifolius raddi. Therapy. Rats. 


\section{Introduction}

Generalized peritonitis is a life threatening disease caused in the majority of cases, by perforation of the digestive tract. Sometimes, this disease can be controlled by local defense mechanisms ${ }^{1}$.However, if these mechanisms fail, the peritoneal cavity is flooded with bacteria, inflammatory mediators and visceral contents. It will turn into one large inflamed compartment in which the local defense mechanisms may become detrimental to the patient. The main risk factors for mortality in this disease are: patient age, the presence of small bowel perforation, a delayed initial intervention (a delay exceeding 24 hours), ICU admission, patient immunosuppression, and renal and respiratory comorbidities ${ }^{2,3}$. Secondary peritonitis is associated with in-hospital mortality rates of approximately $30 \%{ }^{4-6}$.

Bacterial translocation and sepsis are natural consequences when peritoneal defense mechanisms cannot cope with the microbiological challenge and thus sepsis remains a persistent problem on intensive care units all over the world. The standard treatment of this condition is based on: intravenous broad spectrum antibiotics, adequate volume resuscitation, cardiovascular active drugs, intensive care support and the implementation of an aggressive surgical control of the infecting source of peritonitis ${ }^{7}$.

Understanding the complex mechanisms of sepsis is the precondition for establishing new therapeutic approaches in this field. Therefore, animal models are required that are able to closely mimic the human disease and also sufficiently deal with scientific questions.

Intra-abdominal substances including several antibiotics have not produced exciting results for treating peritonitis $^{8-10}$ and although the hydro-alcoholic extract of Schinus terebinthifolius raddi (aroeira extract) has been used inside the peritoneum for healing process of gastroraphy and surgical incision of the bladder in rats ${ }^{11,12}$, it has not been tested as antimicrobial agent against severe peritonitis. Owing that the ethanol extract of this plant has strong antimicrobial activity, the purpose of this investigation was to develop an alcoholic extract of the inner bark of the Schinus terebinthifolius raddi and to test the impact on autogenously fecal peritonitis in Wistar rats.

\section{Methods}

The study was performed at Experimental Research Unit - Medical School of Campina Grande - Paraiba. It was approved by the Ethics Committee of the Institution (CEUA).

\section{Botanical material and alcoholic extract preparation}

One kilogram of inner bark of the Schinus terebinthifolius raddi was kept on $1.000 \mathrm{ml}$ of $70 \%$ ethanol alcohol for seven days. The crude extract was concentrated in a rotary evaporator under reduced pressure at $55-60^{\circ} \mathrm{C}$ for solvent total elimination. The material obtained after the concentration showed a brown thick liquid aspect, being stored in refrigerator at $10^{\circ} \mathrm{C}$. Acceptable toxicology was observed injecting up to $4 \mathrm{ml}$ inside the rat abdominal cavity without clinical signs of intoxication.

\section{Animal experiment}

Eight male Wistar (Rattus norvegicus albinus, Rodentia Mammalia) rats aged 12 months weighing 335 to 433 grams $($ Mean $=380.1 \mathrm{~g} \pm 34.4 \mathrm{~g})$ underwent autogenously $10 \%$ fecal peritonitis. It was injected $5 \mathrm{ml} / \mathrm{kg}$ of filtered $10 \%$ fecal suspension in the rat left lower quadrant, according with previous protocol $^{13}$. After 24 hours, in the six survival rats it was injected. The clinical findings were recorded. Following the previous protocol $^{13}$, the four survival rats were euthanized 45 days after the peritonitis induction, and macroscopic findings of residual infection were photographed and recorded for determining the morbidity score $^{13}$.

\section{Results}

Two rats died at the first 24 hours of peritonitis induction, before receiving $4 \mathrm{ml}$ of the inner bark of the Schinus terebinthifolius raddi extract free of alcohol. Their weights were $360 \mathrm{~g}$ and $365 \mathrm{~g}$, respectively. Two more rats died 12 hours after receiving the extract. Their weights were respectively $370 \mathrm{~g}$ and $375 \mathrm{~g}$.

The 4 survival rats presented strong clinical signs of severe infection. They lost weight and behave in a very quiet way, eating very little of the routine meal. At the end of the first week following intra-abdominal extract antimicrobial injection they were far more active and eating almost normal. They start gaining weight and returning to normal life. From this time on they move to a complete normal life without any clinical signs of infection.

At 45 days following peritonitis induction the four survival rats were euthanized and the inventories of the abdominal and thorax cavities were as follow: 
$1^{\text {st }}$ rat: One retroperitoneal blocked abscess measuring $2 \times 1 \mathrm{~cm}$ in the left lower abdominal quadrant was observed. The pus like material from this abscess in resolution phase did not grow any microorganism. The spleen was enlarged. The entire bowel shows no signs of adhesion. It was observed a scar lesion in the left inferior lobe lung. Figures 1 and 2.

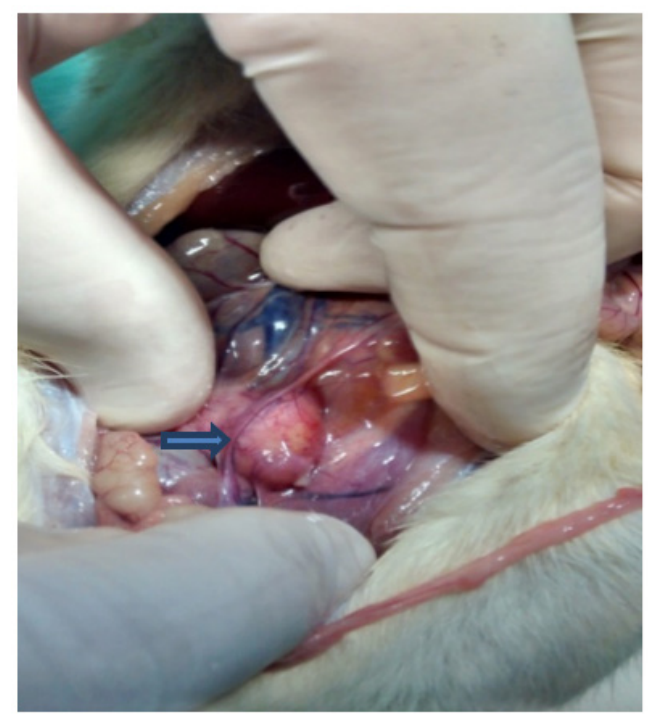

FIGURE 1 - Retroperitoneal blocked abscess located at the left lower quadrant of the abdomen.

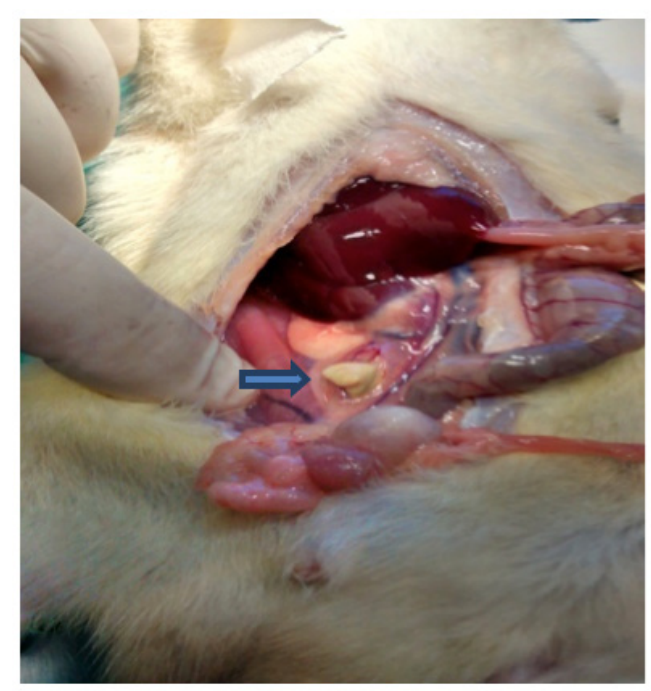

FIGURE 2 - Yellowish necrotic substance coming from the incised blocked abscess. No bacteria grew from this tissue.

$2^{\text {nd }}$ rat: No residual infection sign in the abdominal cavity was observed. The spleen was enlarged. There were no adhesions in the bowel. It was observed a surface scar lesion in the left inferior lobe lung (Figure 3).

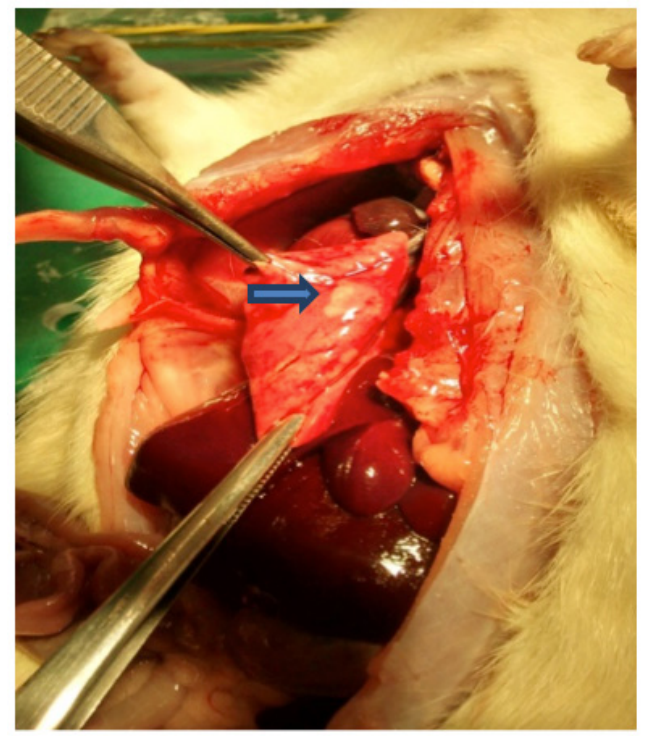

FIGURE 3 -Yellowish scar lesion seen in the visceral surface pleura of the left inferior lobe lung.

$3^{\text {rd }}$ rat: Two retroperitoneal blocked abscesses measuring $2 \times 1 \mathrm{~cm}$ and $0.5 \times 0.5 \mathrm{~cm}$ in the left lower quadrant were observed. The pus like material did not grow any microorganism. It was observed two scar lung lesions. One large lesion in almost the surface of the left superior lobe lung and several small scar lesions in the middle left lung were seen (Figures 4 to 6 ).

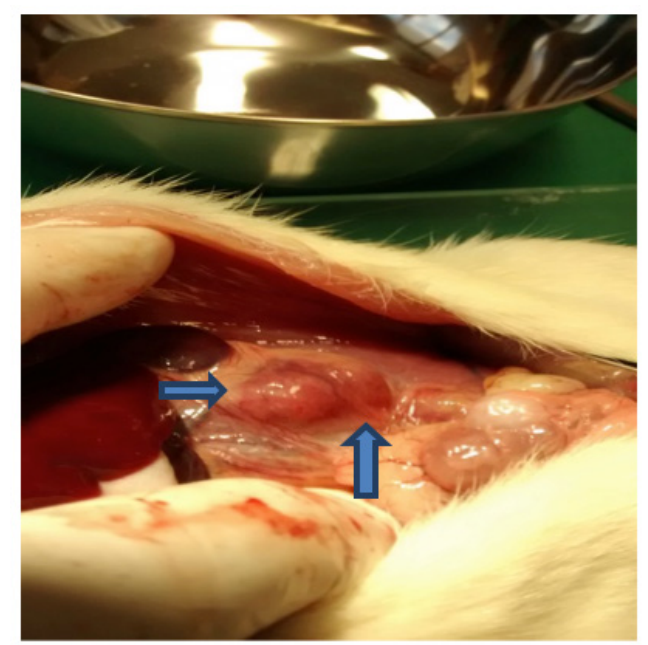

FIGURE 4 - Two retroperitoneal blocked small abscesses in the left lower quadrant. 


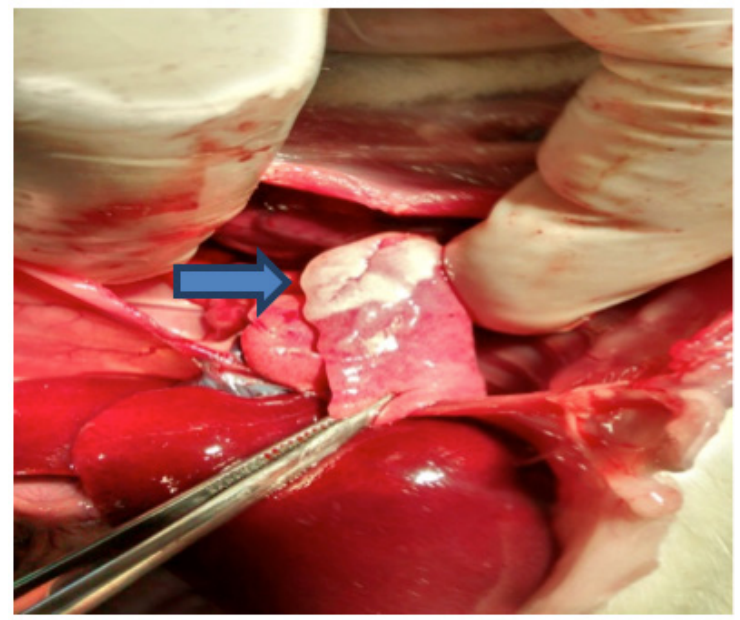

FIGURE 5 - One large lesion in one third of the surface of the left superior lobe lung.

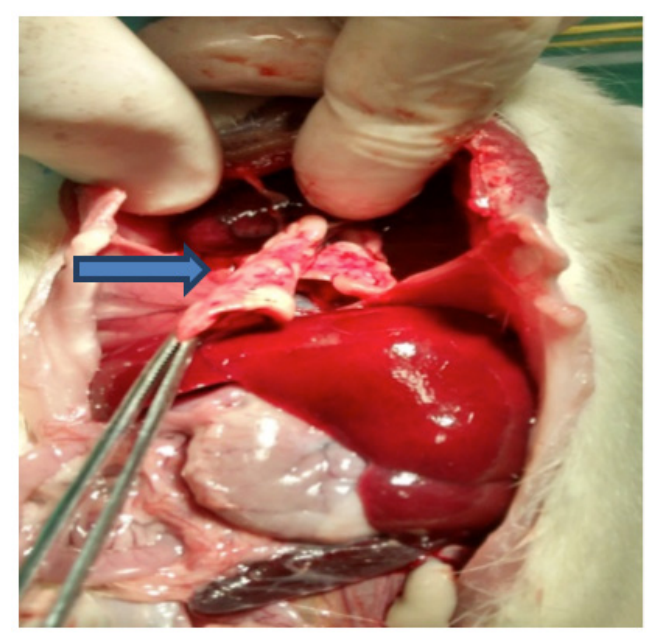

FIGURE 6 - Several scar lesions in the surface of the middle left lung lobe.

$4^{\text {th }}$ rat: There were no residual infection signs in the abdominal cavity. The spleen was enlarged. Small scar lesion was observed in the surface of the middle lobe of the left lung.

The blood cultures of all four survival rats were negative for microorganisms. The morbidity scores, according to previous protocol $^{13}$, of the these rats were respectively: 7, 8, 7 and 8. All four survival rats were living normal life without any symptom or sign of infection.

\section{Discussion}

Intra-abdominal infections represent a common clinical problem, characterized by the presence of purulent secretions and tissue inflammation in this cavity. Peritonitis is often caused by ulcers, appendicitis, diverticulitis, ileus (bowel obstruction), gunshot or stab wounds, and disturbances during abdominal surgical procedures, allowing the escape of indigenous bowel bacteria into the peritonealcavity ${ }^{14}$. The classical and basic treatment for this potential lethal condition is based on the mechanical removal of contaminants, restoration of anatomic integrity of the bowel and systemic administration of antimicrobial agents ${ }^{6,7}$.

Local inflammatory mechanisms triggered by an infection are usually enough to eradicate the pathogen. However, if the infection is not contained, the pathogen, its toxins, and diverse mediators of the host are released to the circulation, producing a systemic inflammatory response syndrome that can cause severe sepsis or septic shock ${ }^{15}$. In this regard, several substances have been used aiming at controlling or modulating the inflammatory cascade that is produced after peritonitis occurs. The results seem to be acceptable ${ }^{16,17}$ however the main goal for treating severe intra-abdominal infection is not dealt in a rational way - it means not battling the overgrow of microorganisms in this cavity or in blood stream.

The hypothesis that an antimicrobial agent placed inside the abdominal cavity is based on the assumption that it will decrease bacterial burden in this space and thus diminishing the possible translocation into the blood stream consequently protecting the life of the animal with severe peritonitis. In this regard several substances including antibiotics, saline solution and antiseptics have been used with no relevant success. However, recently the use of moxifloxacin combined with dexamethasone inside the severe infected abdominal cavity prove to be very promising in decreasing the burden of microorganism into this space and protecting the life of rats with bilateral carotid ligation that underwent severe autogenously fecal peritonitis ${ }^{13}$.

The use of hydro-alcoholic extract of Schinus terebinthifolius raddi (aroeira extract) inside the peritoneum although done for protecting the healing process of gastroraphy and surgical incision of the bladder in rats ${ }^{10,11}$ had not been tested against severe peritoneal infection. This natural substance has been proved, in vitro, to be effective against several microorganisms ${ }^{18}$ and also in vivo in vaginal infection ${ }^{19}$.

All four rats that died in the first 48 hours seem not coping with the initial infection challenge. Although they came from the same group of newborns of two females and one male rats (polygamy pregnancy), their weights were amongst the lower ones. One can speculate that they were suffering from malnutrition and presented with poor immune response. This hypothesis has full support from the literature ${ }^{20}$.

Taking into account that the abdominal cavities of the four survival rats after 45 days of severe autogenously fecal peritonitis were almost free of any sign of infection after the irrigation with the alcoholic extract of inner bark of the Schinus terebinthifolius 
raddi it is advisable to go further in the investigation of its use as adjunctive treatment for severe secondary peritonitis. There may be a role for its use in human beings.

\section{Conclusion}

The impact of alcoholic extract of the inner bark of the Schinus terebinthifolius raddi was considered very positive and promising as natural local antiseptic against very severe peritonitis in Wistar rats, thus offering an alternative for possible adjunctive treatment in human beings with severe secondary peritonitis.

\section{References}

1. Farthmann EH, Schoffel U. Epidemiology and pathophysiology of intra-abdominal infections (IAI). Infection. 1998;26:329-34. PMID: 9795801.

2. Sartelli M, Catena F, Ansaloni L, Coccolini F, Corbella D, Moore EE, Malangoni M, Velmahos G, Coimbra R, Koike K, Leppaniemi A, Biffl W, Balogh Z, Bendinelli C, Gupta S, Kluger Y, Agresta F, Saverio SD, Tugnoli G, Jovine E, Ordonez CA, Whelan JF, Fraga GP, Gomes CA, Pereira GA Junior, Yuan KC, Bala M, Peev MP, Ben-Ishay O, Cui Y, Marwah S, Zachariah S, Wani I, Rangarajan M, Sakakushev B, Kong V, Ahmed A, Abbas A, Gonsaga RA, Guercioni G, Vettoretto N, Poiasina E, Díaz-Nieto R, Massalou D, Skrovina M, Gerych I, Augustin G, Kenig J, Khokha V, Tranà C, Kok KY, Mefire AC, Lee JG, Hong SK, Lohse HA, Ghnnam W, Verni A, Lohsiriwat V, Siribumrungwong B, El Zalabany T, Tavares A, Baiocchi G, Das K, Jarry J, Zida M, Sato N, Murata K, Shoko T, Irahara T, Hamedelneel AO, Naidoo N, Adesunkanmi AR, Kobe Y, Ishii W, Oka K, Izawa Y, Hamid H, Khan I, Attri A, Sharma R, Sanjuan J, Badiel M, BarnabéR. Complicated intra-abdominal infections worldwide: the definitive data of the CIAOW Study. World J Emerg Surg. 2014 May 14;9:37. eCollection 2014. PMID: 24883079.

3. Rausei S, Dionigi G, Boni L, Rovera F, Minoja G, Cuffari S, Dionigi R. Open Abdomen Management of Intra-Abdominal Infections: Analysis of a Twenty-Year Experience.Surg Infect (Larchmt). 2014. PMID: 24797083.

4. Boer KR, van Ruler O, Reitsma JB, Mahler CW, Opmeer BC, Reuland EA, Gooszen HG, de Graaf PW, Hesselink EJ, Gerhards MF, Steller EP, Sprangers MA, Boermeester MA, De Borgie CA. Health-related quality of life six months following surgical treatment for secondary peritonitis - using the EQ-5D questionnaire. Health Qual Life Outcomes. 2007;5:35.PMID: 17601343.

5. Lamme B, Boermeester MA, Belt EJ, van Till JW, Gouma DJ, Obertop H. Mortality and morbidity of planned relaparotomy versus relaparotomy on demand for secondary peritonitis. Br J Surg. 2004;91:1046-54.PMID:15286969.

6. Lamme B, Boermeester MA, Reitsma JB, Mahler CW, Obertop $\mathrm{H}$, Gouma DJ. Meta-analysis of relaparotomy for secondary peritonitis. Br J Surg. 2002;89:1516-24. PMID: 12445059.

7. Bosscha $\mathrm{K}$, van Vroonhoven TJ, van der Werken C. Surgical management of severe secondary peritonitis. $\mathrm{Br} \mathrm{J}$ Surg. 1999;86(11):1371-7. PMID: 10583280.

8. Bosscha K, van Vroonhoven TJ, van der Werken C. Surgical management of severe secondary peritonitis. $\mathrm{Br} \mathrm{J}$ Surg. 1999;86(11):1371-7. PMID: 10583280.

9. Ablan CJ1, Olen RN, Dobrin PB, O'Keefe P, Tatarowicz W, Freeark
RJ. Efficacy of intraperitoneal antibiotics in the treatment of severe fecal peritonitis. Am J Surg. 1991;162(5):453-6. PMID: 1951908.

10. Perdue PW, Kazarian KK, Nevola J, Law WR, Williams T. The use of local and systemic antibiotics in rat fecal peritonitis. J Surg Res. 1994 Sep;57(3):360-5. PMID: 8072283.

11. Santos OJ, Ribas Filho JM, Czeczko NG, Castelo Branco Neto ML, Naufel C Jr, Ferreira LM, Campos RP, Moreira $\mathrm{H}$, Porcides RD, Dobrowolski S. Evaluation of aroeira (Schinus terebinthifolius Raddi) extract on the healing process of gastroraphy in rats. Acta Cir Bras. 2006;21(Suppl 2):39-45. doi. org/10.1590/S0102-86502006000800006.

12. Lucena PLH, Ribas Filho JM, Mazza M, Czeczko NG, Dietz UA, Correa Neto MA, Henriques GS, Santos OJ, Ceschin AP, Thiele ES. Avaliação da ação da Aroeira (Schinus terebinthifolius raddi) na cicatrização de feridas cirúrgicas em bexiga de ratos. Acta Cir. Bras. 2006;21(Suppl 2):46-51. doi.org/10.1590/S010286502006000800008 .

13. Melo MCSC, Gadelha DNB, Oliveira TKB, Brandt CT. Severe autogenously fecal peritonitis in Wistar rats with permanent bilateral carotid occlusion. Response to intra peritoneal moxifloxacin combined with dexamethasone. Acta Cir. Bras. 2014;29(2):76-81. doi.org/10.1590/S0102-86502014000200001.

14. Smith JA. Treatment of intra-abdominal infections with quinolones. Eur J Clin Microbiol Infect Dis. 1991; 0:330-3.

15. Barrera G, Landoni V, Martire-Greco D, Chiarella P, Meiss R, Gomez SA, Alves-Rosa F, Rearte B, Isturiz M, Palermo MS, Fernandez GC. Model of polymicrobial peritonitis that induces the proinflammatory and immunosuppressive phases of sepsis. Infect Immun. 2011;79(3):1280-8. doi:10.1128/IAI.01127-10.

16. Brocco MC, Paulo DN, Baptista JF, Ferrari TA, de Azevedo TC, da Silva AL. Effects of peritoneal lavage with lidocaine on survival of rats with fecal peritonitis. Acta Cir Bras. 2008;23:42-9. doi. org/10.1590/S0034-70942008000500005.

17. Brocco MC, Gomez RS, Paulo DNS, Almeida CED, Baptista JFA. Histological features of peritoneal lavage with ropivacaine in rats with fecal peritonitis. Acta Cir Bras. 2012;27(2):193-9. doi. org/10.1590/S0102-86502012000200016.

18. Silva AB, Silva T, Franco ES, Rabelo SA, Lima ER, Mota RA, Câmara CAG, Pontes Filho NT, Lima-Filho JV. Antibacterial activity, chemical composition, and cytotoxity of leaf's essential oil from Brazilian pepper tree (schinus terebinthifolius, raddi). Braz J Microbiol. 2010;41:158-63. doi: 10.1590/S1517838220100001000023.

19. Leite SRRF, Amorim MMR, Sereno PFB, Leite TNF, Ferreira JAC, Ximenes RAA. Randomized clinical Trial comparing the efficacy of the vaginal use of metronidazole with a Brazilian pepper tree (Schinus) extract for the treatment of bacterial vaginosis. Braz J Med Biol Res. 2011;44(3):245-52. doi.org/10.1590/S0100879X2011007500003.

20. Satyaraj E. Emerging paradigms in immunonutrition. Top Companion Anim Med. 2011;26(1):25-32. doi: 10.1053/j.tcam.2011.01.004.

\section{Correspondence:}

Carlos Teixeira Brandt

Avenida Boa Viagem, 5030/1302

51011-000 Recife - PE Brasil

Tel.: (55 81)3342-0830

carlosbrandt@bol.com.br

${ }^{1}$ Research performed at Experimental Research Unit, Campina Grande Medical School (FCM), Campina Grande-PB, Brazil. 